Impact Factor: 4.845(SJIF) Research Journal Of English (RJOE) Vol-5, Issue-1, 2020

www.rjoe.org.in An International Peer-Reviewed English Journal

ISSN: 2456-2696

Indexed in: International Citation Indexing (ICI), International Scientific Indexing (ISI), Directory of Research Journal Indexing (DRJI) Google Scholar \& Cosmos.

\title{
TRADITIONAL PERSPECTIVES IN THE SELECT NOVELS OF SHASHI DESHPANDE
}

\author{
T.Sailaja \\ Research scholar \\ JNTUACEA \\ Anantapuramu
}

\author{
Dr. V.B.Chitra \\ Professor of English \\ JNTUACEA \\ Anantapuramu
}

\begin{abstract}
India is a country having rich cultural and traditional heritage from ages behind. The culture and traditions of this great country is so opt and ideal for all generations gone by and for future also. Shashi Deshpande to a greater extent has highlighted these traditions in her novels. The author has fully involved her characters depicting the orthodoxical traditions. Present paper describes the traditional outlook of the characters and their conflict between tradition and modernity in a few novels of Deshpande. Two novels are selected for this exercise, they are 'That Long Silence' and 'Roots and Shadows'.An effort is made to bring out the incidents where traditional practices are predominant and noteworthy in these novels .Apart from this the reluctance of the main character to follow the traditional ideals is also depicted in this paper.
\end{abstract}

Key Words: Tradition, Orthodox, Modernity

Shashi Deshpande was born in 1938 in Dharwad in Karnataka state. She is the second daughter of the famous Kannada dramatist and Sanskrit scholar, Sri Adya Ranga Charya (Sri Ranga). She graduated in the field of Journalism from Bhartiya Vidya Bhavan, Mumbai. She is a postgraduate in English from Mysore University. Shashi Despande worked as a journalist for the magazine- 'On Looker'. Later on she switched on to be a novelist. Shashi Deshpande concentrates on the problems and concerns of the middle class Indian women. She brings out a picture of real life of a woman in her novels. The choice of the names of the characters in her novels is also very ideal. Her feministic characters deal with contradictions, paradox, traditions in human relations. Women occupy a central stage in her novels. Quiet obviously she sympathises women characters vividly.

To date Shashi Deshpande has written 11 novels. Her first novel, 'The Dark Holds No Terrors' was published in June 1980. Later on, 'If I Die Today' (1982), 'Roots and Shadows' 
Impact Factor: 4.845(SJIF) Research Journal Of English (RJOE) Vol-5, Issue-1, 2020

www.rjoe.org.in An International Peer-Reviewed English Journal

ISSN: 2456-2696

Indexed in: International Citation Indexing (ICI), International Scientific Indexing (ISI), Directory of Research Journal Indexing (DRJI) Google Scholar \& Cosmos.

(1983), 'Come Up and Be Dead' (1983) came one after the other. She is an awardee for the Sahitya Akademi Award in 1990 for the book, 'That Long Silence' (1988). Thirumathi Rangammal Prize is conferred on her name. Later on, 'The Binding Vine' in 1992, 'A Matter of Time' (1996) came up. 'Roots and Shadows' bagged the award best Indian novel of 198283. The novels 'Small Remedies' in 2000, 'Moving On' in 2004, 'In The Country of Deceit' in 2008, 'Ships that Pass' in 2012 and 'Shadow Play' in 2013 followed one by one. Shashi Deshpande has also authored many a short stories noteworthy to mention are 'The Legacy and Other Stories' (1978), 'It was Dark' (1986), 'The Miracle and Other Stories' (1986), 'It Was The Nightingale' (1986) and 'The Intrusion and Other Stories' (1994). Her books for children included, 'A Summer Adventure' (1978), 'The Hidden Treasure' (1980), 'The Only Witness' (1980) and 'The Narayanapur Incident' (1982). Though all her works are women centred, she refers herself as a non-feminist.

The main character in the novel That Long Silence is Jaya who is a very traditional woman discharging her duties very sincerely of an ideal Indian woman. She is basically a very good writer from her childhood days. After her marriage to Mohan she puts a pause to her inner ability of writing. Entangled in the family problems she devotes herself entirely for the needs of the family. Mohan, as a government employee, in the middle of the story loses his job, for his misdeeds. Jaya's zeal to create her identity in the society is kindled and she starts to regain her identity.

Jaya and Mohan are blessed with two children Rahul and Rati. The other important character in the novel is Kamat who is the neighbour of Jaya. Kamat always motivates and encourages Jaya. She gains lot of potential and restarts writing career. As such Kamat comes very close to Jaya and their mental relationship becomes thicker. When Mohan is suspended from his job Jaya will be forced to support the family inspite of her introvert nature. Jaya becomes a creative writer and proves her identity with the help of Kamat. Kusum, the distant cousin of Jaya is a mentally disordered character in the novel. Mukta is a widow who is a neighbour of Jaya. Asha is Jaya's sister-in-law and Leena is a close friend of Jaya. Mohan' sister is Vimala.

The heroine Jaya is a well educated, knowledgeable, a reserved, dedicated woman. Her inner writer was still active even after her marriage, she wrote a short story book which bagged first prize and was published in a magazine.Jaya's attachment to her father Vasu was closer than with her mother. She got married to Mohan and adjusts to the surroundings after her marriage. Mohan changes her name to Suhasini who becomes a symbol of a submissive housewife. Suhasini symbolizes.

"And I was Jaya. But I had been Suhasini as well. I can see her now, the Suhasini who was distinct from Jaya, a soft, smiling, placid, 
Impact Factor: 4.845(SJIF) Research Journal Of English (RJOE) Vol-5, Issue-1, 2020

www.rjoe.org.in An International Peer-Reviewed English Journal

ISSN: 2456-2696

Indexed in: International Citation Indexing (ICI), International Scientific Indexing (ISI), Directory of Research Journal Indexing (DRJI) Google Scholar \& Cosmos.

motherly woman. A woman who lovingly nurtured her family.

A woman who coped" (TLS 16)

Jaya belonged to a Marathi Brahmin family. The obedience of Jaya in her childhood is carried to her adulthood. This continued obedience is very much related in the name of the novel i.e That Long Silence. This silence is not only adopted by Jaya herself but other characters like Kusum, Vanitamami, Mohan's mother and sister Vimala also amidst the agonies of life, maintained perfect silence.

The Indian tradition is that always the wife creates a balance between self and husband, inspite of adverse situations of the family. That is what here Jaya does. She cleverly manages to balance between her husband Mohan and herself. In other words she submits totally to her husband as told in her own voice-"Ours has been a delicately balanced relationship, so much so that, even we have snipped- off bits of ourselves to keep the scales on an even kneel'(TLS140)Jaya recollects the mythical characters like Sita, Savitri and Draupadi that how these characters followed their husband in all situations of life. Jaya also imitates the same to support shown by these characters to her husband Mohan at all times of distress.

She also gives the traditional version of two bullocks yoked together to move forward in the same direction painlessly. This is narrated by Jaya in the following words-"It is more comfortable for them to move in the same direction. To go in different directions would be painful and what animal would voluntarily choose pain?'(TLS 11) The age old Indian concept of man superior to woman is a traditional opinion which is drilled into the minds of girls from their childhood. Jaya is very much influenced by this attitude of mind of the Indian women. She strictly follows this, even infront of her children, Rahul and Rati. The conventional bed time story of the male crow and the female sparrow is deliberately not narrated by Jaya to her kids. She poses the question to herself whether a female can destroy male, as in the story it happens; the sparrow kills the crow cleverly. Jaya avoids telling this story to Rahul as he may accept the male domination and Rati, as she may become more possessive after listening to the story.

The mythical quote - "Na Stri Swatantram Marhati" means a woman is always freedom less. She can never be angry,

"A woman can never be angry; she can only be neurotic, hysterical,

frustrated. There is no room for despair, either. There is only order

and routine, today. I have to change the sheets tomorrow, scrub the bathrooms the day after, clean fridge" (TLS 147-148).

All the decisions in her life are taken by others, starting from her birth to death. In the present context the same tradition is followed by the author with respect to the character Jaya- her father named her as Jaya and sends her to an English convent in her childhood. 
Impact Factor: 4.845(SJIF) Research Journal Of English (RJOE) Vol-5, Issue-1, 2020

www.rjoe.org.in An International Peer-Reviewed English Journal

ISSN: 2456-2696

Indexed in: International Citation Indexing (ICI), International Scientific Indexing (ISI), Directory of Research Journal Indexing (DRJI) Google Scholar \& Cosmos.

After his death, Jaya's elder brother Dinakar decides everything for her like education, selection of spouse and so on. After her marriage with Mohan, he decides everything for Jaya. Her silence for all the decisions taken by others is an indication that she is very traditional in her attitude. Throughout the novel Jaya never questions for anything that came her way. Her silence is the only answer for all and is an apt name of the novel. This is sadly told by Jaya in the following lines. "I' $\mathrm{d}$ felt not just inconsequential but wholly blotted out... I had learnt it at last- no questions, no retorts. Only silence”

The traditional male perception of blaming others for their mistakes is also highlighted by the author. Mohan's nature is dominating throughout the novel. He decides all the matters relating to the house and for assurances he would ask Jaya. After the bribery scam in Mohan's office, he puts the blame on Jaya and children that he did it for their sake. This is very positively accepted by Jaya as she supports Mohan's activity. The traditional outlook of an Indian husband and wife seen here.

\section{"Roots and Shadows"}

The main character in this novel is Indu, who leaves her house at the age of eighteen to marry Jayant of other caste by her own choice. Akka, a rich and childless widow decides to in her brother's house after her husband's death. Akka opts Indu as an heiress for her property despite the opposition by her family members.Akka represents an age old Brahmin orthodox traditionally bound woman. She is a widow who practices untouchability very strictly. After 11 years Indu returns back to her ancestral place to attend the funeral ceremony of Akka and gets back to her husband. She tells in her own words as, "Ten years I stayed away from this house. And yet, each day of these ten years, I woke up to the same sounds. For a few seconds of each day, I was back in this house. But this time it was real.(R\&S, 34)

Mini is Indu's cousin who is very traditional, obedient, and innocent and sticks to words of her family members. She portrays an ideal Indian woman. Her financial background is very poor. Her father Anant decided to marry Mini to a distant relative of Akka. This decision was not whole heartedly accepted by Mini. Her mute attitude made the decision, a reality.The other characters in this novel include Kaki, Sumitra, Kamala, Sunanda and Atya. These female characters are more superstitious and have influenced Indu verymuch in her childhood days.Indu returns back to her husband's house with a staunch determination of establishing herself. She feels a sense of completeness and wholeness, "I had felt incomplete, not as a woman, but as a person and in jayant I had found the other part of my whole self' (R\&S 51). The story ends up with Jayant recognising Indu's strength and accepting her to live a happy life.

The heroine in the novel, 'Roots and Shadows' is Indu. She is a representative of an educated, clever, sensitive, smart woman of a middle class family. Indeed she is good writer 
Impact Factor: 4.845(SJIF) Research Journal Of English (RJOE) Vol-5, Issue-1, 2020

www.rjoe.org.in An International Peer-Reviewed English Journal

ISSN: 2456-2696

Indexed in: International Citation Indexing (ICI), International Scientific Indexing (ISI), Directory of Research Journal Indexing (DRJI) Google Scholar \& Cosmos.

for magazines. Unfortunately she writes what suits the magazine suppressing her conscience, so she compromises with the hypocrite society. All her academic achievements, economic independence and individual attitude were not valued by the women of older generation.Indu had been rebellious since her childhood itself. She condemns the superstitions beliefs followed by the veterans of her family. She opposes the Hindu tradition of women eating in the dirty plate eaten by her husband. She boldly challenges these traditions. She defies the worn out traditions and pushes aside all her fears. Opposing the traditional and conventional role that she had to play, she seeks fulfillment in education and her career.

On the other hand the character Akka is very orthodox and representation to the extent that she refuses to go to hospital in her last stage also, because of the fear of getting polluted by the touch of nurses belonging to the other castes. Indu is in a paradoxical situation. Indu in her own words tells, "This is my real sorrow, that I can never be complete" (R\&S 34). She was told that the traditional Indian women should be quiet- as a child she has to be obedient and unquestioning, as a girl she had to be meek and submissive and as a female she has to accept everything. A distinction between a traditional woman and modern woman is shown by the author. Thus through this character Shashi Deshpande symbolises a modern woman who is on the verge of transformation.

\section{Conclusion:}

Jaya and Indu are the heroine characters in the novels "That Long Silence" and "Roots and Shadows" respectively. Also the age old traditions that are followed by the character Jaya and rebelled by Indu in these novels are also explained. At last it is seen that Jaya breaks her silence and understands the truth of life. She follows the path of philosophy, religion and mythology, which becomes a part and parcel of humanity. The quote- "There is no sorrow on this earth that heaven cannot heal" is made true by the author throughout the novel and hence Sashi Deshpande becomes a unique writer. In the novel Roots and Shadows the traditional insights of Indu are depicted. Lastly Indu disperses a ray of hope.

\section{References:}

- Deshpande Shashi. 1983. Roots and Shadows. Orient Longman, Hyderabad. Pp.54.

- Deshpande, Shashi. Interviewed by Malini Nair "The Message is incidental", Times of India No.25, Nov 1989.

- Deshpande, Shashi. That long silence. New Delhi: Penguin Books, 1998. Print.

- Atrey, Mukta, Viney Kirpal. Shashi deshpande: A Feminist Study of Her Fiction. New Delhi: D.K Publishers. 1998. Print.

- Sharma, Siddhartha.Shashi Deshpande's Novels: A Feminist Study. New Delhi: Atlantic Publishers, 2005.Print. 
Impact Factor: 4.845(SJIF) Research Journal Of English (RJOE) Vol-5, Issue-1, 2020

www.rioe.org.in An International Peer-Reviewed English Journal

ISSN: 2456-2696

Indexed in: International Citation Indexing (ICI), International Scientific Indexing (ISI), Directory of Research Journal Indexing (DRJI) Google Scholar \& Cosmos.

- Joshi, P.G.Shashi Deshpande's Fiction: A Study in Women Empowerment and Postcolonial Discourse. New Delhi: Prestige Books, 2003.Print.

- Sharma, Siddhartha.Shashi Deshpande's Novels: A Feminist Study. New Delhi: Atlantic Publishers, 2005.Print.

- Dr Tukaram S. Swant, Shashi Deshpande's 'Roots And Shadows': A Tragic Tale Of The Female Plight And Predicament, IJELR, Vol. 3. Issue.3. 2016 (July-Sept.)

- Dr. G. Kiran Kumar, The Delineation Of Human Relationships In Shashi Deshpande's Fictions, Ijelr, Vol.2.Issue. 3.2015 (July-Sep), pp 93-102

- Khushbu Akash Trehan, Shashi Deshpande's That Long Silence: The Inevitable Silence of an Indian Woman, GEORJ, Vol. 1 Issue 3 - December 2015, pp 138-143

- R. Kumara Swamy, The New Woman in Bharati Mukherjee's Wife and Shashi Deshpande's That Long Silence: A Comparative Study, The Criterion: An International Journal in English Vol. 6, Issue. VI December 2015 pp 174-180

- Dr Tukaram S. Swant, Shashi Deshpande's 'Roots And Shadows': A Tragic Tale Of The Female Plight And Predicament, IJELR, Vol. 3. Issue.3. 2016 (July-Sept.)

- Anu Nagar, Conflicts In The Novels Of Shashi Deshpande: A Study Of That Long Silence And The Dark Holds No Terrors, Vol.4.Issue 3. 2016 (July-Sept.) pp 322-328 